\title{
10. A New Family: Domesticity and Sentiment among Chinese and Western Women at Shanghai's Door of Hope
}

\author{
Sue Gronewold \\ Kean University
}

\section{Introduction}

On a winter's eve in 1902, Wu Li-tsu arrived at the doorway of Shanghai's Door of Hope, a Christian rescue mission for Chinese prostitutes that had been opened a year before by an interdenominational committee of Western women. ${ }^{1}$ Ten years before, Wu had been sold to a bad-tempered madam in a nearby brothel as a shu-yu, a high-class "sing-song" girl, and had been severely mistreated. Learning of a new place in the neighbourhood that took in women like her, she managed to escape and find it. Welcomed by its first resident missionary, Cornelia Bonnell, and a Chinese matron, Wu that night began her seventy-year association with the Door of Hope. One of the first five residents of the mission, she was protected, converted, educated and trained. She rose to fill nearly every position a Chinese woman could hold at the home and eventually founded her own refuge, extending her Chinese variant of the mission's work to the wider city of Shanghai. ${ }^{2}$

Like others who entered the mission home, Wu was cared for both physically and spiritually. By 1915, the missionaries regarded her as so pious that they

\footnotetext{
1 The Door of Hope Mission was - and still is - well-known in Shanghai, China, and abroad through standard missionary and philanthropic networks, but many of its records were either destroyed or scattered and are difficult to access. I found general materials - annual reports and other publications by the mission - in the standard US Protestant mission archives, primarily those at New York's Union Theological Seminary, Yale and Harvard Divinity Schools, Chicago's Moody Bible Institute, and Shanghai's now-closed mission library. But to obtain personal details of those affiliated with the mission - its residents, Western and Chinese workers and supporters - I had to locate them or people who knew them, both in China and abroad. I also had to consult specialised archives, such as those of The Evangelical Alliance Mission (TEAM) in Wheaton, Illinois, and the Billy Graham Archives at Wheaton College, Illinois, and special files in the Shanghai Municipal Archives. Locating both people and materials was more difficult because by the 1910s the Door of Hope Mission was linked to informal faith and holiness networks rather than to more official mainline Protestant Christian denominations. The mission's public, often sensationalist, stories, on the other hand, were closely followed by the periodical press in Shanghai.

2 Door of Hope Annual Report 1915, p. 8; 1925 p. 5; 1937, p. 35.
} 
often asked her to lead prayer meetings for the entire mission. Quick at her studies, according to Bonnell, within a decade Wu not only instructed children in the mission, she also helped the missionaries themselves in their constant struggles with the Chinese language. She served as matron of one of the six cottages set up for the smallest charges, many of them young girls sold into prostitution by relatives unable or unwilling to care for them. Realising early on that she was, in the missionaries' words, "not called to marry but to work for other souls instead," Wu acted frequently as a go-between, arranging and overseeing acceptable marriages for "girls" at the mission, making it truly a "door of hope" in a culture where nearly all women married and these women's choices otherwise would have been severely limited.

With all the wartime hardships of 1937 Shanghai, Eleanor Woo-the Christian name given Wu Li-tsu at her baptism - felt "called" to set up a refuge on her own for homeless women, even though she was then sixty-five years of age. Keeping in touch with the Door of Hope, she agreed to oversee both the mission and her own refuge during the Japanese occupation of Shanghai, when most foreigners were interned in camps. When missionaries were forced to leave Shanghai and the Door of Hope in 1951, eventually moving to Taiwan to open another mission, they kept in contact with her. As a result, she was denounced by the new Communist regime as a foreign lackey, removed from her job, and thrown out of her home. She had to live with her sister in what had been a one-family courtyard house now crowded with other families. The regular remittances the missionaries surreptitiously sent were the only thing that kept her from starving. In 1969, she died, age 93. The last thing Li-tsu requested, according to her sister, Li-the, was that she (Li-the) write a letter to the missionaries, inquiring about their health, and thanking them again for all they had done for her. ${ }^{3}$

This chapter focuses on women at the Door of Hope, both the Western missionaries and Chinese women like Eleanor Woo, and my attempt to understand their particular relationships within the mission home - the place to which they came, worked and together forged a new model of domesticity. In Mao's China, it was the formative memory of that model which sustained Eleanor Woo physically, spiritually, and most importantly for this chapter, emotionally, through her old age. Nothing I knew about Western imperialism or Chinese patriarchy had prepared me to understand the lasting power of the bonds within that place — what historian Sylvia Van Kirk calls "tender ties"4_ which I nearly missed in my initial readings of the Door of Hope material.

3 Wu Li-the, Shanghai, China, to Beatrice Lawler, USA, October, 1969, in Door of Hope correspondence files, TEAM.

4 Sylvia Van Kirk, "Many Tender Ties": Women in Fur-Trade Society in Western Canada, 1670-1870, Winnepeg: Watson and Dwyer, 1980, reprint, Norman: University of Oklahoma Press, 1983. 
Focusing on the domestic aspect of the imperial project is not new. In earlier works like Patricia Hill's The World Their Household, Jean Gelman Taylor's The Social World of Batavia, Pat Grimshaw's Paths of Duty: American Missionary Wives in 19th-Century Hawaii, Lenore Manderson and Margaret Jolly's edited volume, Sites of Desire/Economies of Pleasure, scholars extended and complicated the nineteenth-century notion of a "women's sphere" from the metropole to the colony as Anglo-American women increasingly went abroad, whether as missionaries, travellers, teachers, social reformers or companions to travelling men. Scholars have written about a "manifest domesticity" in American expansionism. ${ }^{5}$ A whole genre of feminist scholarship has conclusively argued that constructing the domestic was not secondary but deeply implicated in the entire project of imperialism.

In exploring the new model of domesticity that developed at the Door of Hope, this chapter will focus particularly on the emotional bonds that were a key aspect of its new domestic arrangement. Fortunately, scholars of empire and gender have turned their attention recently to sentiment, emotion, feelingthose powerful but less visible bonds - that connected colonised and colonists in a wide variety of ways. Historians, anthropologists, psychologists, even neuroscientists, scholars like Ann Laura Stoler, Margaret Jolly, Catherine Hall, Lisa Loewe and Emma Rochschild have argued that, in Stoler's words, these "tense and tender ties" are only comprehensible when placed within the racialised hierarchies and their strict boundaries that are fundamental to political and political systems but exaggerated in colonial circumstances. ${ }^{6}$ This "affective turn" in the literature comes at a crucial moment in my own work when I was challenged to make sense of life stories like those of Eleanor Woo.

5 Building on earlier work on women's sphere by Mary Ryan, The Empire of the Mother: American Writing about Domesticity, NY: Institute for Research in History and Haworth Press, 1982; and Nancy Cott, The Bonds of Womanhood, New Haven: Yale University Press, 1978. Scholars who applied this notion to women abroad include Patricia Hill, The World Their Household: The American Woman's Foreign Mission Movement and Cultural Transformation, 1870-1920, Ann Arbor: University of Michigan Press, 1985; Jean Gelman Taylor, The Social World of Batavia: Europe and Eurasian in Dutch Asia, Madison: University of Wisconsin Press, 1983; Lenore Manderson and Margaret Jolly (eds), Sites of Desire/Economies of Pleasure: Sexualities in Asia and Pacific, Chicago: University of Chicago Press, 1997; Patricia Grimshaw, Paths of Duty: American Missionary Wives in Nineteenth-Century Hawaii, Honolulu: University of Hawai'i Press, 1989; Ian Tyrell, Women's Work/ Women's Empire: WCTU in International Perspective 1880-1930, Chapel Hill: University of North Carolina Press, 1991.

6 The work of Stoler is relevant to my search for understanding the emotional bonds that connect at least certain of the Door of Hope former residents with the missionaries who worked among them. See especially her Carnal Knowledge and Imperial Power: Race and the Intimate in Colonial Rule, Berkeley: University of California Press, 2002, especially chapters 1 and 7 and the Epilogue. Stoler's work adds the history of imperialism to the growing sub-field of "affective studies" encompassing history, anthropology, psychology and neuroscience. See, for example, Jan Plamper, "The history of emotions: an interview with William Reddy, Barbara Rosenwein, and Peter Stearns," History and Theory 49 (2010): 237-65; and Patricia Ticineto Clough and Jean Halley (eds), The Affective Turn: Theorizing the Social, Durham: Duke University Press, 2007. To the growing list of historians who examine the emotional life of empire, see also the work of Emma Rothschild, The Inner Life of Empires: An Eighteenth-Century History, Princeton: Princeton University Press, 2011; and Linda Colley, The Ordeal of Elizabeth Marsh: A Woman in World History, London: Pantheon, 2007. 
Searching out the literature that explores the bonds of empire is useful in many ways, yet the Chinese experience in general and the women at Shanghai's Door of Hope Mission in particular are distinct in a number of ways, and comparisons with women intent upon imposing new images of the domestic (and finding that they had to adapt to local realities) in Australia, Indonesia, the Pacific Islands, South Africa, even India, are not precisely equivalent. Not entirely colonised but what scholars call "semi-colonised," not a "settler" society but a millenniaold, still-powerful, extensive empire struggling under the combined challenges of internal turmoil and foreign penetration, China presented a complex case both for colonists and colonised, with its diversity, sheer size, and myriad levels of response and resistance. ${ }^{7}$ Luckily, with increasing access to archives, memoirs and the voices of many of the actors themselves, we can begin to untangle the complex narratives of power and resistance - which is what I set out to do using the Door of Hope as my entry point. Applying these new ideas to the study of the Door of Hope can also bring into sharp relief the tensions and paradoxes inherent in the domestic missionary project.

\section{The Door of Hope and a new domesticity}

For many years I have been fascinated by the story of the Door of Hope, founded by Western women who had been shocked to see prostitutes carried around the streets of the turn-of-the-century treaty port Shanghai advertising the brothels that owned them. Their responses grew out of nineteenth-century notions of urban reform, the power of Christian evangelism, and the civilising mission of enlightened (white) women removing (they called it rescuing) darker-skinned indigenous women from sinful, depraved conditions and transforming them in new domestic spaces, such as existed around the world from London, San Francisco, Buenos Aires to New York. Established at a missionary conference in Shanghai in 1900 and opened in 1901, by 1905 the Door of Hope housed seventyfour women and children. By 1910 it held 325, and even during the Japanese occupation from 1937 to 1945 it managed to stay open and house several hundred. It lasted postwar until the Communist expulsion of Western missionaries in 1951. Home to freed prostitutes (not always by their choice), mistreated concubines and servants, and cast-off "extra" women and children, the mission provided shelter and services generally unavailable to such marginalised females,

Work on emotion and history in non-Western thought has just begun, see Joel Marks and Roger Ames (eds), Emotion in Asian Thought: Dialogue in Comparative Philosophy, New York: State University of New York Press, 1995; and Gayatri Chakravorty Spivak, "Subaltern studies, deconstructing historiography," in Selected Subaltern Studies, ed. Ranajit Guha and Gayatri Chakravorty Spivak, Oxford: Oxford University Press, 1988, pp. 1-34.

7 For literature on Chinese missions, see especially Jane Hunter, The Gospel of Gentility: American Woman Missionaries in Turn-of-the-Century China, New Haven: Yale University Press, 1984. 
from health clinics, schools and tidy cottages, to the more regimented chapels and industrial workshops, and thus it was generously supported throughout its history by Shanghai governments, both Western and Chinese. Over a fifty-year span, it reached some 5,000 women and children directly and many thousands more through its neighbourhood day schools, revivals, and prayer services. The Door of Hope, I discovered, is familiar to scholars of missions and students of Shanghai, Chinese Christians and supporters abroad. Neighbourhood "grannies" in both the People's Republic of China (PRC) and Taiwan remember the Door of Hope and thus could pass their stories on to me. Furthermore, it was an institution that lasted, in part, for the ways it served multiple agendas, but just as much, I began to suspect, because of the less visible but more powerful social dynamics that operated inside its new kind of domestic space.

To mine the stories I collected for details of the lives of both Western and Chinese women like Wu Li-tsu (Eleanor Woo) and, furthermore, to attempt to understand their interior lives, is a daunting task. Most of the stories about them have been at several removes - in the pages of reports, pamphlets and newspapers, ${ }^{8}$ both Chinese and Western, and in the memoirs of missionaries, businesspeople, authorities and reformers, both Chinese and Western. Furthermore, these narratives are incomplete. They relate one incident of rescue, of marriage, of conversion, of baptism, or of an unusual challenge or hardship. They describe a particular aspect of work, schooling or training. They recount wartime turmoil and trials, hasty moves and military attacks, the closing of homes and opening up of branches. And they are stories told for the purposes of fundraising, evangelism or even entertainment - for outsiders, not for those within.

By 1998, I had nearly resigned to telling the story of the women at the Door of Hope by proxy - and predominantly a Western one at that. That spring, I travelled to Shanghai for several months of research with the goal of better understanding the many worlds of Shanghai in which the mission had moved. I found extraordinary material in the Shanghai Municipal Archives: names of all inmates and their backgrounds, mission statements, lists of supporters, plus files of similar institutions both Western and Chinese in the years between 1937 and 1951. But I was predominantly limited to outsider stories about those at the Door of Hope Mission, and I could get no further in my attempt to understand their interior lives and the domestic bonds that held them.

Finally, careful networking within the Chinese Christian community led to an invitation by a local minister to meet "a few" women in his congregation who had been residents at the Door of Hope. In the upper room of an old church, around a table spread with memorabilia, he introduced me to eleven womenand a few men - in their seventies and eighties, all wearing the standard dark

8 See, for example, Shen pao, 1910-40. 
pants and somber tops preferred by older Chinese adults. On closer inspection, I saw that the women had added festive touches: a lighter blouse, a colourful scarf, a hand-knit sweater. It was Easter, one of two times each year when surviving Door of Hope alumnae still gather in Shanghai to catch up, enjoy each other's company, reminisce about the past, and witness for their faith. These former Door of Hope residents were eager to show me what they had managed to save from their years at the mission and to tell me their stories, even interrupting each other in their enthusiasm.

I spent perhaps twenty hours over a several week period with these women and men alumnae (plus many hours in subsequent years), collecting their life histories and listening to their individual stories - and those of others like Wu. For the first time I had evidence of the interior life of the mission and of the powerful ties that still bind them to the memories of the departed missionaries.

Afterwards, exhausted from recalling memories and sharing their emotions from the past, they walked with me to a nearby restaurant where we ate lunch and sang Methodist hymns familiar to me from my Illinois farm childhood. As we parted, a few of them offered to accompany me the next day to the mission's last sites: the larger refuge now a city middle school, while its smaller buildings that once served as chapel and clinic now home to multiple families. Shanghai's traditional architecture of long lanes off main thoroughfares has been remade and reordered, making old addresses difficult to find without the help of someone who has watched the city change. These Door of Hope alumnae served literally as my guides, and their stories shone new light for me on the mission's domestic space and the relationships within it - while presenting new paradoxes to ponder.

\section{Reconstructed stories}

The stories I heard from these former residents modified, expanded and, frankly, complicated the earlier narratives I had constructed of lives at the mission. Not only do these narratives add crucial pieces of information, they also reflect emotional attachments that still endure. Hearing these elderly former residents recollect their lives forced me to imagine the world as they had perceived it - or, more accurately, the world as they now remember perceiving it. ${ }^{9}$

9 Many historians are rethinking the connections between history and memory, especially those who rely extensively on oral history. See, for example, the work of Charlotte Linde, Life Stories: The Creation of Coherence, Oxford and New York: Oxford University Press, 1993; Sherna Berger Gluck and Daphne Patai, Women's Words: The Feminist Practice of Oral History, New York and London: Routledge, 1991; and Barbara Meyerhoff, Remembered Lives: The Work of Storytelling, Ritual, and Growing Older, Ann Arbor: University of Michigan Press, 1992. Two anthropologists of Asia whose work is informed by this more reflexive approach 
Their stories alter my earlier narrative in several key ways which underscore the importance of the mission, its residents, and its missionaries in their lives and they in the missionaries' lives both in the past and in the present. First and foremost, for all the rational reasons I had accumulated for authorities and families to place extra women and children there, I was unprepared for the reasons those elderly people in Shanghai themselves stressed: they had comeor had been brought - to the Door of Hope to be saved. For former residents, the missionaries at the Door of Hope had quite literally and without question saved them.

Christian conversion was always the most important goal for the missionaries, stressed in their literature, their stories, and the neon sign announcing "Jesus Saves" that illuminated their rescue room in the heart of the brothel district after 1929. Their shared Christian belief was undeniably important to each and every one of the alumnae I met who had kept their faith across decades of persecution by a state now turned relatively tolerant. Yet I was struck by how they stressed salvation of a different sort.

In interviews with me, former residents highlighted instead how the missionaries at their new home had saved them literally. They had saved them from neglect, abuse and even starvation. They had saved them from the grueling life of a peasant or the harsh work in textile mills. They had saved them from concubinage or marriage to a bad husband. One woman who had brought her hand-written life history interspersed with red-inked biblical quotes (like Jesus' quotes in her Bible) kept insisting that I take note of these details: at the Door of Hope the missionaries gave them three meals a day, and each meal always consisted of "three rices" plus biscuits and fruit. These former residents kept admonishing me: "Write that in your book."

When I pressed them to tell me their first impressions of the mission home and those within it, certain that this line of questioning would extract some "pure" memories of surprise or fear, one woman without hesitation recalled her first memory: waking up to warmth, with a missionary coming into her room carrying a charcoal brazier. "It was the first time I had been warm in the morning in winter," she said, ${ }^{10}$ and more than sixty-years later she could still recall that sensation of warmth and the missionary who brought it.

The key realisation for me, then, was of the importance for these women of both the safe, secure and warm mission space and of the relationships they

are Lisa Rofel in her study of Chinese women silkmakers, Other Modernities: Gendered Yearnings in China After Socialism, Berkeley: University of California Press, 1999; and Dorinne Kindo, Crafting Selves: Power, Gender, and Discourses of Identity in a Japanese Workplace, Chicago: University of Chicago Press, 1990.

10 From my conversations with former Door of Hope residents at the Moore Protestant Church in Shanghai, China, 19 and 25 of April, 1998. 
formed within it. Coming from precarious lives, for most of them the mission's comforting, domestic space, literally a new home, was paramount. Equally so for the way they spoke of their Chinese "sisters," occasional "brothers," "cousins," older Chinese "aunties," and missionary "aunts" and "mother." From the perception of these elderly Chinese former residents, the people at this transplanted (and adapted) Western institution had quite literally become their family and the mission their new home, in theory to be replicated outside when they left. Most of them have memories of (and some kept links with) their natal Chinese families, ${ }^{11}$ but at least for the younger ones at its Children's Refuge, this new mission family became their dominant kinship group. I was familiar with what anthropologists call "fictive kin" (which is more accurately recast as "constructed kin"), 12 but I had never tried to imagine those relationships from the perspective of the young Chinese. I now realise that I had limited my conceptualisation of the mission and its workers to the Western perspective of social welfare and control, looking at it as a "total" institution and, furthermore, as one among many in the city, from prisons and brothels to hospitals and schools. For the men and women in Shanghai who were children inside its walls, however, it was a family filled with "sisters," "aunties," and "cousins," all led by a "good mommy." It was these people, not some amorphous "institution," that had rescued them, given them food and shelter, clothes and dolls and education. "They," not "it," found husbands for them who, I was told, were even referred to as the mission's "sons-in-law." Mission reports hid the crucially important New Year's gifts these men dutifully gave the Door of Hope each year as filial Chinese husbands of the mission's "daughters." Like dutiful Chinese daughters, the women learned the lessons their family in this mission home had taught them, becoming good preachers and teachers, seamstresses and singers. But the stories of Eleanor Woo and the Shanghai alumnae suggest that the bonds between these women and those who worked at the Door of Hope were even deeper than I had imagined.

All manner of relations within the mission were expressed in kinship terms. For example, the elderly respondents spoke of three "generations" of women and children at the mission: those who had joined it pre-1927, residents from 1927 to 1945 , and residents from after the war. Those with whom I spoke in Shanghai represented the second generation, with only one woman who had become

\footnotetext{
11 It is a truism in the study of prostitution worldwide, however, whether in Shanghai (Gail Hershatter, Dangerous Pleasures: Prostitution and Modernity in Twentieth Century Shanghai, Berkeley: University of California Press, 1999) or New York (Christine Stansell, City of Women: Sex and Class in New York, 1789-1860, Urbana: University of Illinois Press, 1987) that prostitutes generally kept contact with their natal families and in fact more often than not moved in and out of prostitution, depending on the vagaries of their families' economic health. The main support for this argument in the case of the Door of Hope is the contact that former residents seemed to keep with the mission.

12 See Jessica Hinchy, "Deviant Domesticities and Sexualised Childhoods: Prostitutes, Eunuchs and the Limits of the State Child 'Rescue' Mission in Colonial India," this volume.
} 
another's adopted daughter coming from the third. Furthermore, these three generations hold special pride of place within the Shanghai Christian community. Like modern-day apostles they are seen as specially privileged because of their direct contact with the Western missionaries. That special relationship lends them an almost sacred esteem within their current community.

Looking at the history of the Door of Hope Mission in light of the importance of the familial relationships within it made other previously murky aspects more comprehensible. In times of turmoil, I knew, the mission had always been filled to overflowing, with little room for missionaries to accept the refugees that thronged into the relative safety of the city. I had interpreted this lack of receptivity as callousness. I now see it instead as the mission's inability to turn away its adult children who expected they could always come back to it for refuge - frequently bringing their husbands, children and mothers-in-law too. In other words, this Western mission gave priority in Chinese fashion to its obligations to its scattered kin who in times of hardship looked to it - their family in a new domestic space-for welfare and refuge.

In sum, I now realise that all connections, all reference to the mission for them was - and had always been-relational, a relationship, I must underscore, between Western women and Chinese women, but for them defined in familial Chinese terms. The language of family and filiality formed the basis of their ties: obligation, responsibility, respect. And for them - as for Eleanor Woo - the ties were powerfully binding across the years.

\section{Missionaries forging families}

For the Western resident workers at the Door of Hope, by the same token, the mission offered similarly important relationships and a new community, defined for them, however, in Western kinship terms. Pious and poorer than many others in the missionary world, often older and relatively uneducated, the Western women who spent their lives at the Door of Hope were also drawn to rescue work by the relationships they developed within. They formed lifelong friendships with their colleagues at the mission, and it was with these women that they lived, worked, travelled and often retired. Furthermore, it is the inherently unequal relationship within the mission between the Western missionaries and both their Chinese charges and helpers that suggests an even more powerful reason for these Western women's choice of rescue work: the attraction of working in an environment with such gratifying "relations of rescue," a concept described vividly in Peggy Pascoe's work. ${ }^{13}$ In the language of

13 Peggy Pascoe, Relations of Rescue: The Search for Female Moral Authority in the American West 18741939, New York: Oxford University Press, 1990. 
the mission's reports and missives, the missionaries were the maternal rescuers and their "girls" at the mission were victims needing rescue-abused slaves, mistreated servants, and very young brothel inmates - those whose stories they selected for inclusion in their writings and speeches and who confirmed the vision of their work and their roles at the Door of Hope.

Nothing describes the way the missionaries viewed their "girls" better than the poetry composed especially for it. This poetry was standard mission practice, and several of the Door of Hope missionaries, like Gladys Dieterle and Winifred Burlinson, both at the Children's Home, proved adept at writing it. The 1924 and 1925 Annual Reports, sent out to the religious worlds in both China and abroad, are filled with poems by Burlinson that describe one young girl, renamed Precious Blessing by the missionaries. The rhetoric in these poems highlights the pervasive family tropes of the mission-along with their inherent racial, sexual and moral hierarchies.

\section{Precious Secrets}

A little girl before me,

With eyes aglowing stands;

"O see what I am holding

Dear Auntie, in my hands.

This is my share of peanuts,

Today is "peanut day,"

Will you not have some, Auntie?

You may have some, you may."

"I thank you little Love-Heart,

But then you have so few,

Just give me one to taste by

For they were meant for you."

Thus waiting in the garden

Or 'neath the window pane,

Are little hearts and voices,

The touch of love to gain.

“O Auntie, I must tell you

What Precious said today:

I heard her tell the children

While at their merry play

She would not mind if Jesus

Would send her Christmas night.

A little baby dolly

With hair all fair and bright. 
She said it would not matter

If nothing else were given,

Could only one real dolly

Come down to her from heaven!"

And thus we see the longings

Of little Chinese hearts,

For joys we once have tasted

In large or smaller parts.

"I like to sing dear Auntie, That song you taught today;

It makes me feel so happy

At home, at school, at play.

How strange that God should love me,

Sometimes I am not good,

And often I must grieve Him

Not smiling when I should.

I heard you say this morning,

That Jesus died for me;

He must have loved me truly

To bear that awful tree."

And thus the lambs are carried

To Christ's own loving breast

And thus we are rewarded,

Entrusted, crowned, and blessed.

A hundred precious secrets,

Our Love School daily tells,

Of little loves and longings

Of "if's" and "how's" and "well's;"

And feet that pitter-patter

So often past our door,

Have only come to tell us

That love that's needed more.

A hundred tiny faces

Each day uplifted so,

We cannot help but love them,

We cannot say them no. 
God's little Chinese children,

Sweet flowerets of his care,

Some day you'll find them blooming

In Heaven's Garden fair. ${ }^{14}$

This poem aptly illustrates the familial relations of rescue as understood by Western women at the mission. Not only sentimentalising, it reduces all their charges to their children, all missionaries not just to superior benefactors, but more importantly, to older and thus authority figure relatives - to "aunties" and "mothers." Full of imperial assumptions (all that a Chinese girl wants is a fairhaired doll which looks not coincidentally like her missionary "auntie"), the poem reduces the missionary-Chinese relationship to one of maternal Western women (almost all unmarried without children), serving child-like faces "uplifted" to them, without any sign of intransigence, ambivalence, or resistance. ${ }^{15}$

But was that the way in which the individual missionaries thought of their charges? The missionaries liked to think of those faces as belonging only to little children plucked from dens of vice. In point of fact, poems and pictures to the contrary, the "girls" they dealt with were quite often young women by either Chinese or Western standards, from ages twelve to eighteen and even beyond. The reasons they were brought to the mission were not only for purposes of rescue but were, increasingly, for urban removal, social control and refugee relief. Casting them all as needy "children" within a mission family both shortened and lengthened the distance between them and the missionaries. Making all the missionaries into relatives who were superior but familial to them-"mothers" and "aunties" (the same language used by the resident girls and young women, of course) - suggested a closeness, intimacy, yet generational hierarchy that justified the control they asserted over their charges. ${ }^{16}$

If relations within the mission were framed as involving mothers/daughters (and aunts/nieces), then it followed that for Western missionaries the sentiment most appropriate to those relationships was love. Given the Door of Hope's goal, articulated in 1901, "not to reform but to transform," we might today better characterise its methods as "tough love." "Tough," because rescue work was physically arduous and frequently involved force and involuntary confinement, and "love" because it was informed with the nineteenth-century sentimental view which stressed the powerfully binding "cords of love." This emphasis on

14 Door of Hope Annual Report, 1925, pp. 14-15.

15 See Barbara Brenzel, "A study of the socialization of wayward girls," in Harvard Educational Review 50(2) (May, 1980): 196-213; and the articles in Mary T. Huber and Nancy C. Lutkehaus (eds), Gendered Missions: Women and Men in Missionary Discourse and Practice, Ann Arbor: University of Michigan Press, 1999.

16 See Mary Louise Pratt's discussion in Imperial Eyes: Travel Writing and Transculturation, London and New York: Routledge, 1991, p. 36. Identifying them as subordinate children also justified the imperial, imperious tone the missionaries affected, in their reports, in their work and, one suspects, in relating to "their girls." 
what Barbara Brenzel calls "compulsory love"17 is clear in the names given to parts of the mission, from the "Love School" (the children's home) to the "love friends" (donors who sponsored individual children).

It may seem paradoxical, but even during their most difficult times, with obstreperous youths, scarcity of funds, or turmoil in the city, the missionaries at the Door of Hope Mission in their reports and correspondence continued to stress the word "love." The Annual Report in one particularly challenging year (1915) was filled with the word: its title was "The Story of Love," the chapters were "Love Sought," "Love Taught," "Love Planned," "Love Guided," "Love Supplied," "Love Multiplied," "Love Saved," "Love Kept" and "Love Filled."18

Clearly, family "love" in a new domestic space was seen as the answerfor everything. But the "love" that the missionaries brought to the mission was characterised by the maternal feelings that one had for subordinate (and insubordinate) children. It was not accidental that the preponderance of biographies in the reports highlighted girls from the Children's Home rather than older "girls" and former prostitutes. This "love" was never an emotion exchanged between equals; it was always offered from a superior to an inferior, from a parent to a child, from a saved to a sinner - from a coloniser to a colonised. It was not tender, neither was it unconditional or passive. If enough love was given, if the mission and missionaries within it were infused with it just as the reports and the correspondence were, then all the difficulties they encountered in the world could be overcome- and their charges would be both rescued and saved. ${ }^{19}$

Like the missionaries themselves, the language of their interior lives was forceful, powerful, transforming - and imperial. Through the power of their love as forged in this new mission family and within the new domestic space, the missionaries believed they could save all of China. ${ }^{20}$

\section{Families forged and reinterpreted}

Domestic family affection, then, formed the dominant missionary discourse at the Door of Hope and the key to the relationships they developed-and maintained-within it. As is clear from the preceding discussion, however,

\footnotetext{
17 In her study of female reformatories, Brenzel addresses this issue, emphasising its unequal nature and its force. See Benzel, "Study of Socialization," p. 212.

18 Door of Hope, Annual Report, 1915, pp. 1, 3, 5, 7, 9, 12, 15 and 18.

19 In this regard, Mary Louise Pratt's notion of "anti-conquest" is particularly instructive here, by which she notes the Western women's fantasy that spiritual and material conquest could be achieved without violence. See Pratt, Imperial Eyes, pp. 7, 33.

20 Again, see Brenzel, "Study of Socialization," p. 212. She sees evidence in this language of "love" of the nineteenth century sentimental view of rescue work which emphasised the strong "cords of love" binding rescued and rescuers together. She also emphasises its unequal nature and its force, calling it "compulsory love."
} 
Chinese and Western women framed and interpreted those relationships differently - each from their own cultural and historical perspective, with transcultural adjustments constantly being made.

Recognising that the Door of Hope is a textbook case of what Charles Hayford has called a "transplanted" institution ${ }^{21}$ —run by working-class Westerners in alliance with elite Chinese - for poor, problematic Chinese women, all working from different perspectives and norms. Given that Door of Hope alumnae were severely persecuted in Mao's China for their former connections with Western imperialists, how did these familial relationships survive for seventy-five years, with an impact and emotional power still felt, both in Shanghai and Taipei?

In the end, the Chinese women's view of the stern, authoritarian Dieterle, the German missionary-director of the mission during much of its history, was the most difficult for me to reconcile. Nevertheless, their memory might hold the key to the paradox presented by the bonds of sentiment. At the end of my interviews with the elderly women in 1998, I finally understood my share of the bargain they had implicitly made: they were patiently waiting to question me and for me to tell them the end of the story that they had never heard: the fate of the Door of Hope missionaries after leaving Shanghai, especially that of Dieterle, the director, the woman they called "the good mommy." And when I gently told them that she had retired to the United States and died in a missionary retirement community in Nebraska, they were shocked and silent. "Oh, she died!" they said collectively, several of them wiping away tears. I realised that to these former "girls" at the mission she had been frozen in time, forever the mother who had rescued and saved them. But their feelings for her went beyond filiality and obligation, and instead encompassed a profound, nearly limitless emotion.

In my reading of the documents, Dieterle came across as stern, cruel and perhaps even sadistic (reinforced by their stories of her withholding food, love and approval when they were "bad," while doling out favours, including allowing girls to sleep in her bed at night, when they were "good"). By contrast, to them she was not just maternal and caring but was the ultimate hao p'o ma or good mommy.

Although their links to a foreign mission had caused them tremendous suffering, especially during the Cultural Revolution, in their view it had ultimately been the reason for their salvation and survival, and had, as their family, sustained them through both good and bad times, including giving them strong beliefs to hold onto in the otherwise alienating China of today.

21 Charles Hayford, To the People: James Yen and Village China, New York: Columbia University Press, 1990. 
I had expected to find gratitude and obligation, as in the last words of Eleanor Woo. I was unprepared for the powerful emotional bonds that stretched across the century. In their minds and memories, the missionaries' "former girls" in Shanghai were linked powerfully and emotionally to each other and to the missionaries, especially to the good mommy. Western missionaries, on the other hand, with their language of love and sentiment, paradoxically presented themselves as stern maternal rescuers, rigidly religious and morally upright. They had a language of love and sentiment, but their behaviour appeared to have no room for the overwhelming expressions of true sentiment I saw in Shanghai.

\section{Domestic bonds across time and space}

In the fall of 2000, I had another experience with women from the Door of Hope that shed more light on these relationships and helped me understand the mission's complicated reworkings of Christian and Confucian, colonial and contemporary values and sentiments.

Kathyrn Merrill grew up in an evangelical southern California family that had donated generously to the Door of Hope in the 1930s, and Dieterle became a powerful role model for the young Kathy. When the mission moved to Taiwan in the 1950s, Merrill became a missionary and followed Dieterle at the Door of Hope Children's Refuge in Taipei. It was a different kind of ministry - as much social work as Christian sermonising, given the turmoil of a rapidly modernising city $^{22}$ and by 1976, after the mission was disbanded, Merrill staffed the Door of Hope Center, doing missionary work while dealing with all manner of urban problems, staying close to the several generations of young women she had helped both spiritually and materially at the Door of Hope Children's Refuge. ${ }^{23}$ Those who knew Merrill in Taiwan described the maternal relationship she had with her charges, "Her love for children suited her for mothering these girls." ${ }^{24}$

After retiring to her home town of Santa Barbara, California, in 1999, Merrill was diagnosed with cancer. I visited her there only a few weeks before her death and was able to talk with her at length, continuing the conversations and sharing of documents that had begun nearly ten years earlier. I was also able to observe Merrill interacting with her natal family, members of her home church

\footnotetext{
22 For an extensive discussion of the Door of Hope experience in Taiwan, see Sue Gronewold, "From Shanghai to Taipei: exile and identity," in Women in the New Taiwan: Gender Roles and Gender Consciousness in a Changing Society, ed. Catherine Ferris, Anru Lee, Murray Rubinstein, Armonk, NY: M.E. Sharpe, Inc., 2004, pp. 59-75.

23 That Merrill's work was critical to the modernising state was made clear in 1999 when Taiwan's Ministry of the Interior honoured her for her work with Chinese girls. See "A brief sketch of Kathy's life" from the program "Memorial Service for Kathy Merrill," April 6, 2000. Personal gift to me from Lorna Chao, who was brought up by Kathy at the Door of Hope in Taipei, and who was active in organising the memorial service. 24 Quoted in "A brief sketch of Kathy's life."
} 
and, most importantly, the unending stream of Chinese women "alums" who flew at great expense from Taiwan and other points abroad to be with her in her last days. Speaking and breathing with great difficulty, propped up in a special hospital chair, she had immense dignity and maintained total control over the situation. Her agenda with me was clear: she realised that she would not be able to write the history of the mission and was passing the baton on to me. ${ }^{25}$ Merrill wanted to bring me up to date with the last stories of her "alums" the most recent weddings and new babies named after her, new conversions and solutions found to problems with the law, with jobs, with cruel husbands, abusive boyfriends or wayward adolescents. ${ }^{26}$ She let me select and photocopy from the stacks of photograph albums, personal letters and missionary missives she had carefully organised and brought with her. And she wanted me to meet the many women gathered around her, who graciously included me. Not once did Kathy waver. Warm, loving, and certainly maternal, her style was at the same time controlled and measured.

The women around her were the antithesis of such control. Kathy greeted each one privately as they arrived and hurried in to see her, spending long sessions behind the closed door. "Alums" who had not seen each other in years embraced and comforted each other. I was there for several days and the scene constantly repeated itself, with grief-stricken women coming and going. From time to time, one of the group would have to leave, returning to a demanding job or family. The outpouring of grief as they bid goodbye to Kathy, knowing it was for the last time, was difficult to bear. This was not mere obligation and respect that I was witnessing. For these women, Kathy was indeed their beloved mother to whom they owed so much and were forever attached by deep and profound personal connections. ${ }^{27}$

A hundred years, many miles, and many changes separate Eleanor Woo's entering Shanghai's Door of Hope from the goodbyes I witnessed in Santa Barbara. But there is much that is the same. Whether in Shanghai, the PRC, or in Taipei, Taiwan, whether in the last years of the Qing Dynasty or in the years of the

25 Kathy Merrill was also very grateful to me for making the initial contact with the Door of Hope alumnae in Shanghai and for alerting them about her. After retiring from mission work, she had in fact been able to take advantage of my contacts and visit Shanghai in June, 1999, making the circle complete.

26 In addition, Merrill made one demand very clear. She had read some of my writings on the Door of Hope and quietly but firmly insisted that I make a crucial change: the young women and girls at the Door of Hope were not "inmates," a word I had used throughout. To describe them in this Foucauldian manner reduced the relationship to one simply of jailer and jailed, which was completely unacceptable to her. In her view, the relationship was one of spiritual guide and wandering pilgrim, teacher and student, mother and daughter. See Michel Foucault, Discipline and Punish: The Birth of the Prison, trans. Alan Sheridan, New York: Random House, 1977.

27 Although it is now fourteen years since her death, as many of her beloved "alums" as possible still gather each year in Santa Barbara on the anniversary of her death, remembering the life and legacy of the woman they regard as their mother. Personal communication with Samuel Chao, May 2012, whose wife Lorna was brought up in the Door of Hope in Taipei. 
Taiwan "miracle," needy Chinese women and Western women missionariesthemselves often marginal and searching for meaning - created a new kind of family at the Door of Hope, using much the same language of rescue, conversion, salvation and kinship. The mission served a useful purpose for many in China: from individuals seeking an end to abuse or hunger, to families crushed by life's demands or just plain greedy, to the city and state beset by unwelcome and unexpected challenges. It also served an important role for Western women, offering them a home away from their own often problematic ones, plus a sense of belonging, engagement and, yes, imperial power. It is also clear that for both Chinese and Western women, the Door of Hope was a new domestic space where they forged powerful, long-lasting emotional bonds: Chinese with Chinese, Western women with other Western women, but also Chinese women and "girls" with Western women, bound together in the language of family. Relationships were not equal; imperialism and the constraints of Chinese patriarchy handed Western women most of the power, but Chinese women and girls often struggled to negotiate the terms of their confinement, and the language of kinship and family gave them the tools to do so. In their time at the mission many of them developed abilities and attitudes that fit well into a new China, and for that they were eternally grateful to their missionary "good mommy."

\section{Paradoxes of domesticity and sentiment}

In the end, then, my understanding of the women and their relationships within the Door of Hope mission was rendered more complex than less, more nuanced than clear, and much more powerful than imagined. Door of Hope missionaries came to Shanghai to inculcate the ideals of Western Christian women toward domesticity and the family in their Chinese charges, but over the course of time, both they and their home in China became a hybrid constructed family which arranged marriages for their "daughters," received filial New Year's gifts given to parents, and gave refuge to their former wards' Chinese families in times of trouble. In the process they all created a new model of domesticity in which the institution, paradoxically, became "home" for both the Western missionaries most of them poor, unmarried, older, and thus without a home in the Western sense of what a home should be for women of their age and station-and home for their Chinese charges who had either become estranged from their Chinese homes or never had one, transforming the Door of Hope's institutional buildings and halls into a domestic space in the process.

These relations of rescue paradoxically transformed the strict German director of the Door of Hope, Dieterle, into the "good mommy" the Chinese alumnae remembered, who allowed them to share her bed if they were good and whose 
death they mourned as if it were the passing of their own mothers. In the process, both the mission and the missionaries became constructed kin in Chinese terms, replacing or supplanting their own families.

Finally, the mission that was to save souls for Christ paradoxically was most remembered by the women it saved for its bodily benefits, like three meals a day and a heated bedroom. Just as paradoxically, the unmarried and unwanted US missionary women who came to bring Western ways to the Chinese found status and love in newly constructed Chinese family roles.

Mothers and daughters, love and gratitude, control and devotion, but also imperialist and colonised, dominated and subordinated, sternness and sentiment - these were the paradoxes of domesticity that are revealed in examining the sentiments of empire and relations of rescue among the womenWestern and Chinese - at a door of hope in China.

\section{Acknowledgements}

This his chapter could not have been written without the advice and support of a great many people in both the US and China: my very patient family first and foremost, but also librarians at Union Theological Seminary in New York City, the Moody Bible Institute and the TEAM archives in Chicago, the late Kathryn Merrill of the Door of Hope in Taipei, and, most importantly, the many Chinese Christians connected to the Door of Hope in Shanghai who took a risk and told their stories to an unfamiliar foreign woman intent on passing them on. 
This text taken from Divine Domesticities: Christian paradoxes in Asia and the Pacific, edited by Hyaeweol Choi and Margaret Jolly, published 2014 by ANU Press, The Australian National University, Canberra, Australia. 